\title{
Small Intestine Cancer pT1a TNM Finding v8
}

National Cancer Institute

\section{Source}

National Cancer Institute. Small Intestine Cancer pT 1a TNM Finding v8. NCI Thesaurus.

Code C133838.

Small intestine cancer with tumor invading the lamina propria. (from AJCC 8th Ed.) 